\title{
A review study of the role of genetically modified Lactococcus lactis in prevention of type 1 diabetes mellitus
}

\author{
Abeer Mudhafar Al-Humaidhi ${ }^{\star}$, Ahmed Abdulkareem Shegaya**, Ali Qusay Sagban**, \\ Hussain Ali Jaleel ${ }^{\star \star}$, Karrar Mahtar Ateha**, Maitham Jaber Abdulhussain ${ }^{\star \star}$ \\ *Department of Pharmacology and Toxicology, College of Pharmacy, University of Thi-Qar, \\ ${ }^{\star \star}$ College of Pharmacy, University of Thi-Qar, Iraq \\ Correspondence: abeermudhafar599@gmail.com
}

(Ann Coll Med Mosul 2020; 42 (1):82-89).

Received: $27^{\text {th }}$ June 2020; Accepted: $19^{\text {th }}$ July 2020.

\section{ABSTRACT}

Globally, type 1 diabetes mellitus is a common chronic autoimmune disease that impacts a great number of individuals. It results from devastation of insulin-secreting beta cells of the pancreas described as incompetence to secrete insulin resulting in hyperglycemia that need a ceaseless treatment with insulin. Further, complications of type 1 diabetes can influence numerous organs and may prompt premature death. Therefore, the requirement to find new strategies for managing type 1 diabetes other than exogenous insulin administration got obligatory. Curiously, genetically modified Lactococcus lactis can incite immunological tolerance; downregulate mechanisms linked to adaptive immunity; and reduce disease-related inflammation, while leaving the remainder of the immune system flawless. This review aimed to overview genetically modified Lactococcus lactis, it's expressing proteins, pathogenesis of type 1diabetes, and therapeutic effects of genetically modified Lactococcus lactis in animal model of type 1daibetes, further, to display the possible mechanisms through which the genetically modified Lactococcus lactis can act. It has been presumed that targeting antigen-specific pathway utilizing genetically modified Lactococcus lactis has potential therapeutic impacts in experimental animals with type 1 diabetes mellitus. This could open up new and safe therapeutic prospects in autoimmune disease domain such as type 1diabetes mellitus .

Keywords: antigen specific therapy; bioactive proteins; immune tolerance; Lactococcus lactis; type 1 diabetes.

$$
\begin{aligned}
& \text { دراسة مراجعة لدور المكورات اللبنية نوع لاكتس المعدلة وراثيا }
\end{aligned}
$$

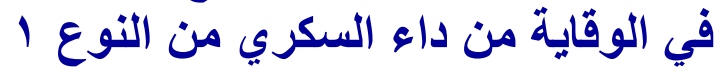

$$
\begin{aligned}
& \text { عبير مظفر الحميضي*، أحمد عبدالكريم شكاية***، علي قصي صكبان***، حسين علي جليل**، كرار محتار }
\end{aligned}
$$

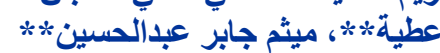

$$
\begin{aligned}
& \text { *فرع الأدوية والسموم، كلية الصيللة، جامعة ذي قار، ذي قار، **كلية الصيدلة، جامعة ذي قار، ذي قار، }
\end{aligned}
$$

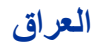

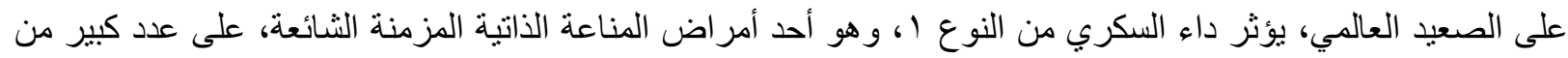

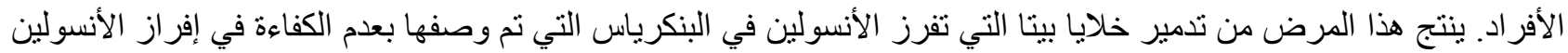

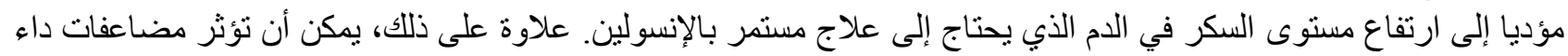

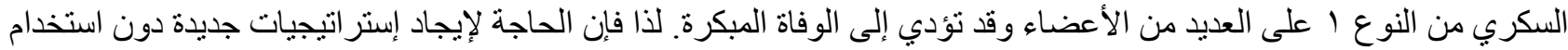

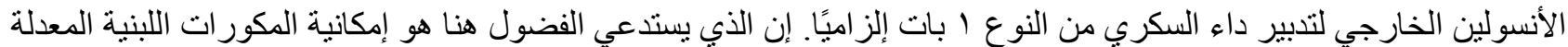

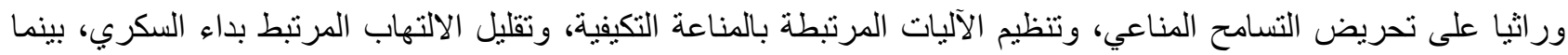

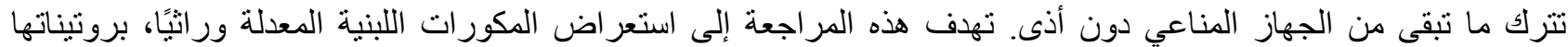

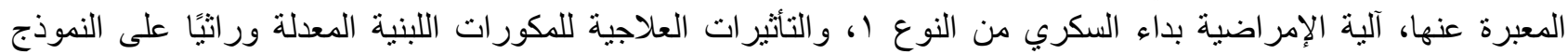

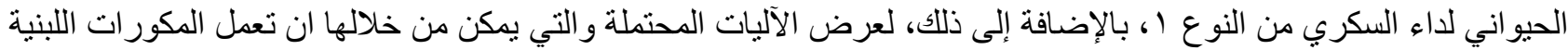

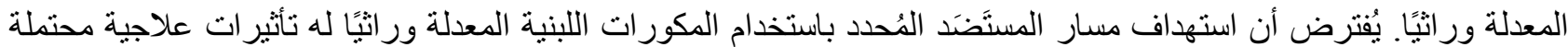




$$
\text { المناعة الذاتية مثل داء التجارب المصابة بداء السكري من النوع أ. هذا بدوره يمكن أن يفتح آفاقاً علاجية جديدة وآمنة في مجال أمر اض }
$$

الكلمات المفتاحية: العلاج المُحدد للمستَضَد، البروتينات النشطة بايولوجيا، التسامح المناعي، المكورات اللبنية، داء السكري

\section{INTRODUCTION}

T ype 1 diabetes mellitus (T1DM) is a chronic autoimmune illness clinically identified by hyperglycemia, resulting from immune-mediated devastation of insulin-creating pancreatic beta cells due to auto-reactive $T$ cells. It shows up at any age, but childhood regarding a particular manner. Globally, its prevalence is evaluated to be upregulated to pass two million cases and to be twofold in children younger than five between 2005 and $2020^{1}$. However, persistent beta cell devastation ultimately leads approximately to complete loss of endogenous insulin creation in practically all patients and the consequent need for exogenous insulin utilization. Further, interminable raised blood glucose can prompt many complications making patients liable for life-long morbidity $^{2,3}$ such as stroke, leg amputation, vision deterioration, nerve damage, renal dysfunction or cardiovascular disease which remains the significant reason of untimely morbidity and mortality ${ }^{4,5}$.

T1DM is presently perceived to result from an unpredictable interchange between microbiome and environmental elements, metabolism, genome as well as immune systems that differ among individuals. Unfortunately, in order to normalize blood levels of glucose, type 1 diabetic patients can just depend on day by day exogenous insulin replacement, which anyway cannot restrain complications, subsequently making it hard to practice ordinary life and typical lifespan.

It is known that immune reactivity in most autoimmune maladies is confined towards a limited number of auto-antigens that is recognized by auto-reactive $T$ cells. Thus, most efforts have been focused on specific controlling on these autoreactive $T$ cells through antigen-specific strategy that consequently leads to tolerance induction, while leaving the rest of the immune system flawless for preventing of T1DM.

Lactococcus lactis (L. lactis) is a spherical and facultative anaerobic gram-positive bacterium, which is utilized in particular food fermentation and can be genetically modified by developed techniques. L. lactis is noninvasive; therefore it has low potential to exert side effects following prolonged use. Moreover, it has revealed that oral administration of recombinant $L$. lactis strains lessens the T1DM onset in experimental animals ${ }^{6}$ via multiple ways, including prompting antigenspecific regulatory $T$ cells, changing the immune response from a devastating (like T-helper 1) (Th1) to a progressively benign (like T-helper 2) (Th-2) response, increment in the interleukin 10 (IL 10) "anti-inflammatory cytokine" and decrease interferon gamma (IFNy) "pro-inflammatory cytokine" which resulted in normalization of hyperglycemia, improved glucose tolerance and diminished insulitis.

This review has been aimed to elaborate $L$. lactis and its expressing proteins, pathogenesis of T1DM, the reasons behind picking of $L$. lactis. It has been further cover the molecular mechanisms beyond reducing T1DM onset and tolerance induction through using genetically modified $L$. lactis as an antigen-specific therapy. Notably, the current review was achieved by searching through PubMed and Google Scholar using "Lactococcus lactis", "Type 1 diabetes", "genetically modified Lactococcus lactis", and "genetically modified Lactococcus lactis in type 1 diabetes". The outcomes have been gathered from various published studies which guide the authors toward multiple findings in treating animal models of T1DM.

\section{The Whys Behind Lactoccous Lactis Choosing}

In the gut of healthy persons, a huge number of commensal bacteria are available which do not elicit an inflammatory response, since gut immune system generate a state that boost tolerance for gut delivered antigens.

L. lactis is a common lactic acid producing bacteria utilized in fermented dairy products manufacturing ${ }^{7}$. The more importantly, the idea 
behind $L$. lactis choosing is that this microorganism is non-pathogenic as well as non-colonizing, further this bacteria has longstanding safety record where it possesses status of GRAS (Generally Regarded As Safe) and has a relatively small genome, simple metabolism ${ }^{8}$, ability to secrete of heterologous proteins to extracellular circumference ${ }^{9}$, and to generate bioactive, eukaryotic derived proteins with a minimal potential to elicit immune system hyper-activation when present in mammalians' mucosa, or side effects related long period utilization ${ }^{10}$.

Consequently, $L$. lactis has been regarded as an interesting cell manufactory for an immune range of a natural products ${ }^{8}$ and as ideal host for delivery of therapeutics like recombinant proteins that act through antigen specific pathway in T1DM without negative impacts on the rest of immune system.

Strikingly, $L$. lactis had been genetically modified to secrete a beneficial auto-antigens aimed to reverse of autoimmune diabetes via its useful reversal of autoimmune diabetes by prompting of antigen specific tolerance.

\section{Genetically Modified Lactococcus Lactis and Expressing Proteins}

The genetically modified $L$. lactis have attracted a significant consideration in the field of diabetes. The advancement has been made with respect to genetic modification as well as to control of gene expression in these organisms ${ }^{11-12}$.

These gram-positive micro-organisms have been developed to survive in the small intestinal media also, their cell envelope structure is beneficial for the secretion of important proteins into the intestinal environment. However, various bioactive proteins are still effectively expressed in $L$. lactis and broadly used in many of preliminary and experimental pharmaceutical studies (Table $1)$.

\begin{tabular}{|c|c|}
\hline $\begin{array}{l}\text { L. lactis } \\
\text { expressing } \\
\text { proteins }\end{array}$ & Results \\
\hline $\begin{array}{l}\text { GAD- } 65^{*} \text { and } \\
\text { interleukin } 10\end{array}$ & $\begin{array}{l}\text { Reverses diabetes in recent- } \\
\text { onset diabetic NOD mice; } \\
\text { preserves beta cell function } \\
\text { and prevents progression of } \\
\text { insulitis; and induces Foxp3+ } \\
\text { Tregs }{ }^{* * 13} \text {. }\end{array}$ \\
\hline $\begin{array}{l}\text { HSP65 } \\
\text { tandem repeats } \\
\text { of P277 } \\
\text { (HSP65-6P277) }\end{array}$ & $\begin{array}{l}\text { Prevents the onset of T1DM; } \\
\text { improves glucose tolerance; } \\
\text { reduces insulitis; inhibits T cell } \\
\text { proliferation; and induces } \\
\text { P277specific tolerance that is } \\
\text { associated with activating T- } \\
\text { helper2 response and } \\
\text { suppressing T-helper1 } \\
\text { response }\end{array}$ \\
\hline $\begin{array}{l}\text { HSP65 } 5^{\star \star *} \text { with } \\
\text { six tandem } \\
\text { repeats of } \\
\text { IA2****2 } \\
\text { (HSP65-6IA2P2) }\end{array}$ & $\begin{array}{l}\text { Prevents the onset of T1DM; } \\
\text { improves glucose tolerance; } \\
\text { reduces insulitis; and } \\
\text { enhances immunomodulatory } \\
\text { response }{ }^{14} \text {. }\end{array}$ \\
\hline $\begin{array}{c}\text { SNase }^{\star \star \star \star \star \star} \\
\text { (staphylococcal } \\
\text { nuclease) }\end{array}$ & $\begin{array}{l}\text { Delays the onset of T1DM; } \\
\text { ameliorates inflammation; } \\
\text { contributes to } \\
\text { immunomodulatory balance; } \\
\text { and control blood glucose } \\
\text { levels }{ }^{15} \text {. }\end{array}$ \\
\hline \multicolumn{2}{|c|}{$\begin{array}{l}\text { * Glutamic Acid Decarboxylase } \\
{ }^{* \star} \text { Regulatory T cells } \\
{ }^{* \star \star} \text { Heat Shock Protein } 65 \\
{ }^{\star \star \star \star} \text { Insulinoma Antigen-2 } \\
{ }^{\star \star \star \star \star} \text { SNase, staphylococcal nuclease }\end{array}$} \\
\hline
\end{tabular}




\section{Pathogenesis of Type 1 Diabetes Mellitus}

The pathogenesis of T1DM is a consequence of a complex interaction among the pancreatic beta cells and innate and adaptive immune systems ${ }^{15,16}$. It can be described by breaking intolerance toward pancreatic beta cells that are responsible for insulin production ${ }^{17}$. Notably, $T$ cells have the substantial role in the pathophysiology of $\mathrm{T}^{\mathrm{DDM}}{ }^{18}$. Additionally, prompting of pro-inflammatory Th-1 with correspond reducing in anti-inflammatory-Th-2 as an immune responses, have been determined in T1DM disease.

Basically, the recent onset of T1DM is correlated with $T$ cells and macrophage infiltration to islet of Langerhans ${ }^{19}$ resulting in a lessen release of insulin, the glucose regulation hormone, leading to blood glucose in elevated levels then insulitis that is observed histopathologically ${ }^{20}$. Thus, antigens of pancreatic beta cells turned to be presented via antigen presenting cells which have infiltrated the islets of pancreas ${ }^{21}$. Then, pathogenic islet antigen-specific group of $T$ cells will be activated and expanded ${ }^{22,23}$. Ultimately, the disturbance will happen in the natural balance between two types of $T$ cells which are auto-reactive $T$ cells and their regulatory ones, leading to breakdown of tolerance then progressive loss of beta cells.

Imbalance of self-reactive CD4+ and CD8+ T cells subsets that are expressed in insulitic lesions may contribute to the development of $\mathrm{T}_{1 \mathrm{DM}}{ }^{24}$. It is important to know that several pancreatic islet auto-antigens contributes to T1DM pathogenesis, of which Heat-shock protein (HSP), pro-insulin, glutamic acid decarboxylase-65 (GAD-65) and islet antigen 2 antibodies $(\mathrm{IA}-2)^{25}$, a tyrosine phosphate like protein, also called ICA152.

Interestingly, in the early stages of T1DM neutrophils can cause pancreatic injury together with auto-reactive macrophages, $T$ cells, dendritic cells, as well as $B$ cells ${ }^{26}$, in which the destructive auto-antigens are essentially coming from both apoptotic beta cells and neutrophil extra-cellular traps (NETs) released via activated neutrophils ${ }^{27}$. Furthermore, it is revealed that high level of glucose and hyperglycemia can enhance NETs release as well as the circulating markers of neutrophil activation and release that is known as (NETosis) $^{28}$.
Therapeutic Intervention of Genetically Modified Lactococcus Lactis in Type 1 Diabetes Mellitus

Genetically modified $L$. lactis have been demonstrated safe, successful, and attractive choice for therapeutic intervention for T1DM through delivering heterologous antigens ${ }^{29}$, antiinflammatory cytokines ${ }^{30}$ or T1DM related therapeutic products gastro-intestinally in a welldefined in vivo models of diabetes such as NOD mice or the bio-breeding rats that develop T1DM spontaneously.

These therapeutic strategies have been exhibited to be due to genetically modified $L$. lactis role in immune system resetting toward beta cell specific tolerance through antigen specific track ${ }^{13}$ as well as in diminishing severe insulitis in newly diagnosed diabetes in NOD mice resulting in reinstates normoglycemia.

Several experimental past studies revealed that orally administered $L$. lactis which have been genetically-modified to secrete human pro-insulin in addition to the immunomodulatory cytokine IL 10 , in combination with sub-therapeutic dose of anti-CD3 monoclonal antibodies can prompt diabetes remission in fifty nine percent of newlyonset diabetic NOD mice ${ }^{13,31}$.

Furthermore, it has been demonstrated that recombinant $L$. lactis secrets two major T1DM related auto-antigens, the 65 kilodalton isoform of glutamic acid decarboxylase "GAD-65" as well as tyrosine phosphatase-like protein ICA512 (IA-2) allowed tolerance induction.

Moreover, it has been revealed that recombinant L. lactis strains delivering HSP65-6P277 peptide were highly diminished the incidence of T1DM. Notably, this peptide has been demonstrated to possess an efficacy in preventing T1DM onset in NOD mice m $^{32,33}$ 
The possible mechanism of action of genetically modified Lactococcus lactis against T1DM

Autoimmune diseases including T1DM have all been linked to an increase in $\mathrm{T}$-helper-1/T-helper17 (Th-1/Th-17) as consequence of an uncontrolled immune reactions ${ }^{34}$. The excess of immune reactivity might be overcome using antigen-specific therapeutics.

Basically, the mechanism of genetically modified $L$. lactis action might be briefed as expressing proteins that are linked to other immune receptors on intestinal macrophages, enhancing them to adopt an anti-inflammatory phenotype. Then, the migration of these macrophages into the pancreatic lymph nodes is followed by inducing regulatory-T cells formation, which in turn repress auto-reactive $T$ cells that are responsible for beta cell devastation ${ }^{17}$. (Figure 1)

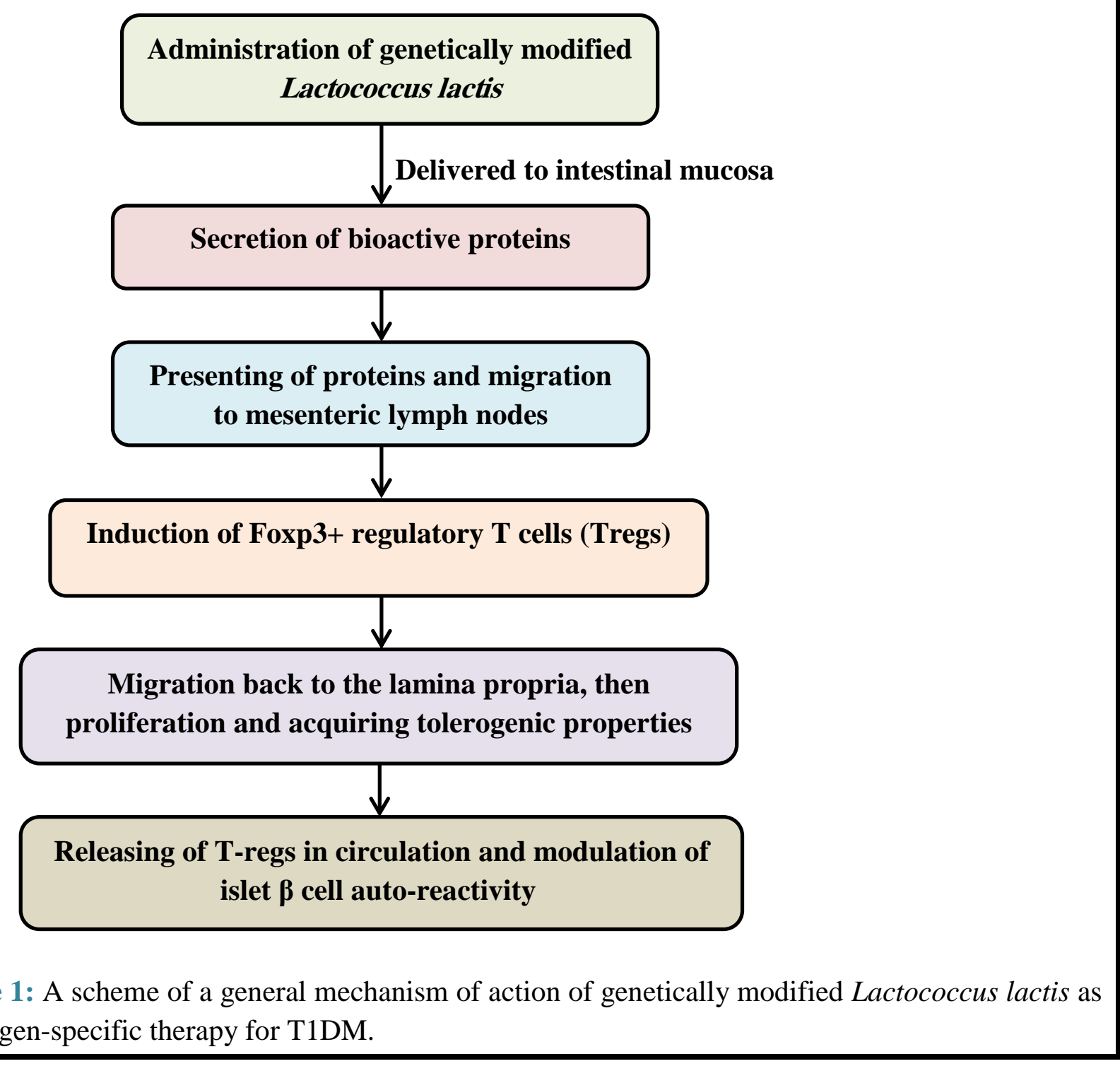


Mechanistically, genetically modified $L$. lactis has a potential to prevent T1DM via induction of antigen-specific Foxp3+ T-regs transfer and homes to Langerhans islets, through gut delivery of beta cell antigens that combined with low doses of antiCD3 monoclonal antibodies, biologically active immunomodulatory ${ }^{31}$. While, the mechanism of recombinant $L$. lactis expressing HSP65-6IA2P2 in prevention of the T1DM onset in NOD mice has been reported to act by induction of antigenspecific immune tolerance ${ }^{14}$ that has been mediated via a prompted regulatory immune reaction that have been acted to balance Th17/Tregs as well as Th1/Th2 ratios. It is important to know that upregulation of interleukin 17 (IL 17), a pro-inflammatory cytokine that are secreted mainly from Th-17 cells resulting in excess expression of FOXP3 transcripts ${ }^{35}$. Interestingly, pancreatic inflammation has been improved following gut delivery for HSP65-6IA2P2. This response also demonstrated an enhanced immune-regulatory mechanism.

On the other hand, the potential mechanism of how HSP65-P277 peptide vaccinates against T1DM might be involved a switch from the proinflammatory Th-1 to the anti-inflammatory Th-2 immune response ${ }^{32}$. With the help of rabbits as an animal model of diabetes that are nasally immunized with the HSP65-6P277 peptide, it has been showed the repression of $T$ cell proliferation as well as increment in IL 10 production, both of these effects demonstrated a remarkable suppression of the Th-1 branch which might be indicated a switch from Th- 1 to Th- $2^{36}$. The mechanism also involved the raise in the levels of IL 10 that has been associated with reduction of IFNy levels which were determined when released by splenocytes isolated from recombinant $L$. lactisadministered NOD mice resulting in a prevention of overt diabetes $^{6}$.

Based on the experimental study that has been utilized the recombinant L.lactis expressing SNase in NOD mice, the mechanism of action has been explained by that the early degradation of neutrophil (NETs) exerted a marked diminishing in serum levels of neutrophil-derived circulating free DNA (cf-DNA/NETs), protease 3 (PR3), neutrophil elastase (NE), further, SNase has been effectively regulated the levels of blood glucose, resulting in delay of T1DM onset as well as reducing the morbidity and mortality. Inflammation has been also ameliorated, as evidenced by the striking raise in interleukin 4 (IL 4), a cytokine secreted and produced via Th-2 cells; consequently the insulitis could be suppressed. Additionally, the significant reduction of both c-reactive protein "CRP" and tumor necrosis factor-alpha (TNF- $\alpha$ ) has been recognized ${ }^{15}$.

Strikingly, through evaluation of liver tissues and serum levels of catalase (CAT), superoxide (SOD), glutathione peroxidase (GSH-Px) activity, and malondialdehyde (MDA) levels in diabetic mice model, it has been demonstrated that L.lactis has antioxidant activity ${ }^{37}$.

\section{CONCLUSION}

The creative antigen-specific strategy utilizing oral genetically modified $L$. lactis augments antigen-specific immune tolerance which results in delaying the onset, reducing insulitis as well as decreasing the incidence of T1DM which could open up a new therapeutic prospects and make a difference in the developing field of type 1 diabetes mellitus remedy. However, further researches are required to prove the outcomes before it can be utilized clinically.

Conflict of Interest: the authors declare that there are no conflicts of interest regarding the publication of this manuscript.

\section{REFERENCE}

1. Bresson D, Togher L, Rodrigo E, et al. Anti-CD3 and nasal proinsulin combination therapy enhances remission from recent onset autoimmune diabetes by inducing Tregs. $J$ Clin Invest. $\quad 2006 ; 116(5): 1371-1381$. doi:10.1172/JCl27191

2. Harjutsalo V, Forsblom C, Groop PH. Time trends in mortality in patients with type 1 diabetes: Nationwide population based cohort study. BMJ. 2011;343(7824):1-11. doi:10.1136/bmj.d5364

3. Mejía-León ME, Calderón de la Barca AM. Diet, microbiota and immune system in type 1 diabetes development and evolution. Nutrients. 2015;7(11):9171-9184. doi:10.3390/nu7115461

4. Lee SI, Patel M, Jones CM, Narendran P. Cardiovascular disease and type 1 diabetes: Prevalence, prediction and management in an 
ageing population. Ther Adv Chronic Dis. 2015;6(6):347-374.

doi:10.1177/2040622315598502

5. Huo L, Shaw JE, Wong E, Harding JL, Peeters A, Magliano DJ. Burden of diabetes in Australia: life expectancy and disability-free life expectancy in adults with diabetes. Diabetologia. 2016;59(7):1437-1445. doi:10.1007/s00125-0163948-x

6. Ma Y, Liu J, Hou J, et al. Oral administration of recombinant Lactococcus lactis expressing HSP65 and tandemly repeated $\mathrm{P} 277$ reduces the incidence of type I diabetes in non-obese diabetic mice. PLoS One. 2014;9(8):1-10. doi:10.1371/journal.pone.0105701

7. Kok J, van Gijtenbeek LA, de Jong $A$, van der Meulen SB, Solopova A, Kuipers OP. The Evolution of gene regulation research in Lactococcus lactis. FEMS Microbiol Rev. 2017;41(1):S220-S243.

doi:10.1093/femsre/fux028

8. Song AAL, In LLA, Lim SHE, Rahim RA. A review on Lactococcus lactis: From food to factory. Microb Cell Fact. 2017;16(1):1-15. doi:10.1186/s12934-017-0669-x

9. Schneewind O, Missiakas DM. Protein secretion and surface display in Gram-positive bacteria. Philos Trans $R$ Soc $B$ Biol Sci. 2012;367(1592):1123-1139. doi:10.1098/rstb.2011.0210

10. Bahey-El-Din M, Gahan CGM. Lactococcus lactis-based vaccines: Current status and future perspectives. Hum Vaccin. 2011;7(1):106-109. doi:10.4161/hv.7.1.13631

11. Guo T, Xin Y, Zhang $Y$, Gu X, Kong J. A rapid and versatile tool for genomic engineering in Lactococcus lactis. Microb Cell Fact. 2019;18(1):1-12. doi:10.1186/s12934-019-10753

12. Börner RA, Kandasamy V, Axelsen AM, Nielsen AT, Bosma EF. Genome editing of lactic acid bacteria: Opportunities for food, feed, pharma and biotech. FEMS Microbiol Lett. 2019;366(1). doi:10.1093/femsle/fny291

13. Robert S, Gysemans C, Takiishi T, et al. Oral delivery of glutamic acid decarboxylase (GAD)65 and IL10 by lactococcus lactis reverses diabetes in recent-onset NOD mice. Diabetes. 2014;63(8):2876-2887. doi:10.2337/db13-1236
14. Liu KF, Liu XR, Li GL, Lu SP, Jin L, Wu J. Oral administration of Lactococcus lactis-expressing heat shock protein 65 and tandemly repeated IA2P2 prevents type 1 diabetes in NOD mice. Immunol Lett. 2016;174:28-36. doi:10.1016/j.imlet.2016.04.008

15. Lang J, Wang X, Liu K, et al. Oral delivery of staphylococcal nuclease by Lactococcus lactis prevents type 1 diabetes mellitus in NOD mice. Appl Microbiol Biotechnol. 2017;101(20):76537662. doi:10.1007/s00253-017-8480-5

16. Hull CM, Peakman M, Tree TIM. Regulatory T cell dysfunction in type 1 diabetes: what's broken and how can we fix it? Diabetologia. 2017;60(10):1839-1850. doi:10.1007/s00125017-4377-1

17. Van Belle TL, Coppieters KT, Von Herrath MG. Type 1 diabetes: Etiology, immunology, and therapeutic strategies. Physiol Rev. 2011;91(1):79-118. doi:10.1152/physrev.00003.2010

18. Battaglia M. Experiments by nature: Lessons on type 1 diabetes. Tissue Antigens. 2014;83(1):1-9. doi:10.1111/tan.12280

19. Imagawa A, Hanafusa $T$, Tamura $S$, et al. Pancreatic biopsy as a procedure for detecting in situ autoimmune phenomena in type 1 diabetes: Close correlation between serological markers and histological evidence of cellular autoimmunity. Diabetes. 2001;50(6):1269-1273. doi:10.2337/diabetes.50.6.1269

20. Campbell-Thompson ML, Atkinson MA, Butler $A E$, et al. The diagnosis of insulitis in human type 1 diabetes. Diabetologia. 2013;56(11):25412543. doi:10.1007/s00125-013-3043-5

21. Sabyasachi C, Kaniz WS, Anupam B MB. Molecular and Immunological Mechanisms of BCell Death in Type 1 Diabetes Mellitus. Res Rev Res J Biol. 2016;4(2):21-23.

22. Knip M, Siljander H. Autoimmune mechanisms in type 1 diabetes. Autoimmun Rev. 2008;7(7):550-557. doi:10.1016/j.autrev.2008.04.008

23. Kathryn Haskins AC. CD4 T cells and their antigens in the pathogenesis of autoimmune diabetes. Curr Opin Immunol. 2011;23(6):739745. doi:10.1038/jid.2014.371

24. van den Brandt J, Fischer HJ, Walter L, Hünig T, Klöting I, Reichardt HM. Type 1 Diabetes in BioBreeding Rats Is Critically Linked to an 
Imbalance between Th17 and Regulatory T Cells and an Altered TCR Repertoire. J Immunol. 2010;185(4):2285-2294.

doi:10.4049/jimmunol.1000462

25. Di Lorenzo TP, Peakman M, Roep BO. Translational mini-review series on type 1 diabetes: Systematic analysis of $T$ cell epitopes in autoimmune diabetes. Clin Exp Immunol. 2007;148(1):1-16. doi:10.1111/j.13652249.2006.03244.x

26. Mócsai A. Diverse novel functions of neutrophils in immunity, infammation, and beyond. J Exp Med. 2013;210(7):1289-1299. doi:10.1084/jem.20122220

27. Leslie RDG, Bradford C. Autoimmune Diabetes: Caught in a NET. Diabetes. 2014;63(12):4018-4020. doi:10.2337/db14-1382

28. Menegazzo L, Ciciliot S, Poncina $\mathrm{N}$, et al. NETosis is induced by high glucose and associated with type 2 diabetes. Acta Diabetol. 2015;52(3):497-503. doi:10.1007/s00592-0140676-x

29. Adel-Patient K, Ah-Leung S, Creminon C, et al. Oral administration of recombinant Lactococcus lactis expressing bovine $\beta$-lactoglobulin partially prevents mice from sensitization. Clin Exp Allergy. 2005;35(4):539-546. doi:10.1111/j.13652222.2005.02225.x

30. Vandenbroucke K, De Haard H, Beirnaert E, et al. Orally administered $\mathrm{L}$. lactis secreting an antiTNF Nanobody demonstrate efficacy in chronic colitis. Mucosal Immunol. 2010;3(1):49-56. doi:10.1038/mi.2009.116

31. Takiishi $T$, Korf $H$, Belle TL Van, et al. Reversal of Autoimmune Diabetes by Restoration of Antigen-Specific Tolerance Using Genetically Modified Lactococcus Lactis in Mice. $J$ Clin Investig http//www.jci.org.

2012;122(5):1717-1725. doi:10.1172/JCI60530DS1

32. Jin L, Zhu A, Wang Y, et al. A Th1-recognized peptide P277, when tandemly repeated, enhances a Th2 immune response toward effective vaccines against autoimmune diabetes in nonobese diabetic mice. $J$ Immunol. 2010;184(8):4575-4575.

doi:10.4049/jimmunol.1090009
33. Liang J, Aihua Z, Yu W, Yong L, Jingjing L. HSP65 serves as an immunogenic carrier for a diabetogenic peptide P277 inducing antiinflammatory immune response in NOD mice by nasal administration. Vaccine. 2010;28(19):3312-3317. doi:10.1016/j.vaccine.2010.02.100

34. Chow J, Mazmanian SK. Getting the Bugs out of the Immune System: Do Bacterial Microbiota "Fix" Intestinal T Cell Responses? Cell Host Microbe. 2009;5(1):8-12. doi:10.1016/j.chom.2008.12.006

35. Honkanen J, Nieminen JK, Gao R, et al. IL-17 Immunity in Human Type 1 Diabetes. J Immunol. 2010;185(3):1959-1967. doi:10.4049/jimmunol.1000788

36. Xiong $Q$, Jin $L$, Li J, et al. A Th2 immune shift to heat shock protein 65 fails to arrest atherosclerosis: Proatherogenic role of Th2deviated autoantibodies. Autoimmunity. 2009;42(6):475-483. doi:10.1080/08916930902887086

37. Guo Y, Pan D, Li H, Sun Y, Zeng X, Yan B. Antioxidant and immunomodulatory activity of selenium exopolysaccharide produced by Lactococcus lactis subsp. lactis. Food Chem. 2013;138(1):84-89. doi:10.1016/j.foodchem.2012.10.029 